\section{Why Are Stock Market Returns Correlated with Future Economic Activities?}

\author{
Hui Guo
}

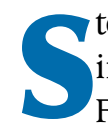
tock price has been found to provide important information about future economic activities. Fama (1981), Fischer and Merton (1984), and Barro (1990), among many others, document a positive relation between stock market return and subsequent growth in investment and output. These findings are consistent with rational expectations asset pricing models, in which stock price is equal to the sum of discounted future cash flows or dividends. An unexpected increase in the stock price indicates that (i) future dividend growth is higher and/or (ii) future discount rates are lower than previously anticipated. Given that the dividend is an important component of gross domestic product (GDP) and is also likely to be positively correlated with the other components of GDP, the stock price increase may merely reflect higher expected future output. On the other hand, lower discount rates are associated with higher investment and, therefore, higher output. ${ }^{1}$ Moreover, recognizing a timevarying risk premium, Lettau and Ludvigson (2001b) show that the $q$ theory of investment implies an important relation between the expected stock market return and investment. That is, lower expected stock market return implies lower future stock price and higher future capital cost; accordingly, investment falls over long horizons.

The analysis above shows that stock returns are correlated with future economic activities through different channels. In this paper, I address the relative importance of these mechanisms by using Campbell and Shiller's (1988) method to decompose excess stock market return, $e_{M, t}$, into three parts: expected return, $E_{t-1} e_{M, t}$; a shock to the expected future return,

Hui Guo is an economist at the Federal Reserve Bank of St. Louis. William Bock provided research assistance.

(1) 2002, The Federal Reserve Bank of St. Louis.

$$
-\left(E_{t}-E_{t-1}\right) \sum_{j=1}^{\infty} \rho^{j} e_{M, t+j} ;
$$

and a shock to the expected future dividend growth, ${ }^{2}$

$$
\left(E_{t}-E_{t-1}\right) \sum_{j=0}^{\infty} \rho^{j} \Delta d_{M, t+j} .
$$

I find that a positive shock to the expected future dividend growth is associated with higher future GDP growth. Contrary to the conventional wisdom, however, dividend shocks are rather weak predictors for economic activities. For example, their forecasting power concentrates on the next four quarters, of which dividend shocks explain only about 2 percent of variations in GDP growth. I find similar results for the GDP components as well. In contrast, the expected return, especially, and shocks to the expected future return exhibit strong predictive ability for economic activities. However, their predictive patterns are quite different: while shocks to the expected future return are positively (negatively) correlated with future investment over short (long) horizons, the expected return is negatively (positively) correlated with future investment over short (long) horizons. As a result, the forecasting power of excess stock market return is considerably compromised. For example, it explains essentially no variations in one-quarter-ahead investment growth, while the three components jointly account for 4 percent. Also, excess stock market return explains only 2 percent of variations in the next three years' investment growth, compared with 13 percent by the three components.

Intuitively, a positive innovation in the dividend indicates greater future economic growth. However, the forecasting power of dividend shocks is moderate because my decompositions show that they account for only a small portion of variations in excess stock market return. The relation between the expected return, $E_{t-1} e_{M, t}$, and future investment

1 According to the $q$ theory of investment, a negative shock to discount rates should increase stock price and investment simultaneously. However, Lamont (2000) argues that there are intertemporal shifts in these relationships because of lags between investment decisions and investment expenditures. His results help explain why, according to the data, stock return is negatively correlated with contemporaneous investment and positively correlated with subsequent investment.

2 Actually, there is an extra term: the shock to the real risk-free rate,

$$
-\left(E_{t}-E_{t-1}\right) \sum_{j=0}^{\infty} \rho^{j} r_{f, t+j}
$$

However, Campbell and Ammer (1993) find that it accounts for very few variations in excess stock market return. For simplicity, I assume that its value is zero in this paper. 
is consistent with Lettau and Ludvigson (2001b), who show that the two variables are negatively correlated in the short run and are positively correlated in the long run. Similarly, because the shock to the expected future return at period $t$,

$$
-\left(E_{t}-E_{t-1}\right) \sum_{j=1}^{\infty} \rho^{j} e_{M, t+j},
$$

is negatively correlated with the expected return at period $t+1, E_{t} e_{M, t+1}$, it should also be negatively correlated with investment in the long run, even though the two are positively correlated in the short run. In other words, an appreciation in stock price may imply either an increase or decrease in future investment, depending on whether such an appreciation in price is due to (i) a negative shock to the expected future return or (ii) to the fact that the stock price is expected to be high. ${ }^{3}$ My results, therefore, explain why the predictive power of stock market returns is rather limited, as argued by many authors (e.g., Stock and Watson, 1999).

Later in the article, I discuss the stock market return predictability and then decompose excess stock market returns. I show forecasting ability of these components for future economic activities and then offer conclusions.

\section{STOCK MARKET RETURN PREDICTABILITY}

In the past two decades, financial economists have documented mounting evidence against the random walk hypothesis of stock price. For example, Campbell, Lo, and MacKinlay (1997) provide evidence that dividend yield and the stochastically detrended risk-free rate contain information about future stock price movements. ${ }^{4,5}$ Lettau and Ludvigson (2001a) find that fluctuations in the consumption-wealth ratio are strong predictors of future stock market returns. Moreover, Guo (2002) shows that past stock market variance has significant predictive ability as well; and, interestingly, such predictive ability is greatly enhanced if the consumption-wealth ratio is also included in the forecasting equation.

Table 1 replicates some results of the predictability of stock market return documented in the early literature. The informational variables include lagged excess stock market return, $e_{M, t}$; the dividend yield, $d p_{t}$; the stochastically detrended risk-free rate, rrel $_{t}$; the consumption-wealth ratio, cay $_{t}$; and past stock market variance, $\sigma_{M, t}^{2}$. I use quarterly data from 1953:Q1 to 2000:Q4, and Appendix A provides details about that data. The first five rows present the univariate regression results. I find that, while $\mathrm{rrel}_{t}, \mathrm{cay}_{t}$, and $\sigma_{M, t}^{2}$ forecast one-quarter-ahead excess stock market return, $e_{M, t}$ and $d p_{t}$ enter the forecasting equation insignificantly. Row 6 is the regression result of excess stock market return on all the informational variables except $\sigma_{M, t}^{2}$. Again, rrel $_{t}$ and cayt are both statistically significant and the adjusted $R^{2}$ is about 12 percent. I add $\sigma_{M, t}^{2}$ as an additional regressor to the multivariate regression in row 7 . Consistent with Guo (2002), $\mathrm{rrel}_{t}, \mathrm{cay}_{2}$, and $\sigma_{M, t}^{2}$ are highly significant and the adjusted $\mathrm{R}^{2}$ jumps to 20 percent! The substantial improvement in the forecasting ability is explained by the fact that, while $\sigma_{M, t}^{2}$ and cay ${ }_{t}$ are negatively correlated, they both enter the excess stock market return equation with a positive sign. To summarize, evidence suggests that a large portion of variations in excess stock market return is predictable.

I want to emphasize that stock price predictability does not necessarily contradict the stock market efficiency hypothesis. This point is clearly demonstrated in Merton's (1973) intertemporal capital asset pricing model (ICAPM), which can be summarized by equation (1a):

$$
E_{t} e_{M, t+1}=\gamma E_{t} \sigma_{M, t+1}^{2}+\lambda E_{t} \sigma_{M F, t+1} .
$$

The conditional excess stock market return, $E_{t} e_{M, t+1}$ (defined as the difference between the conditional stock market return, $E_{t} r_{M, t+1}$, and the risk-free rate, $\left.r_{f, t+1}\right)$, is a linear function of its conditional variance, $E_{t} \sigma_{M, t+1}^{2}$, and its covariance with investment opportunities, $E_{t} \sigma_{M F, t+1}^{2}$. The coefficient $\gamma$ is a measure of relative risk aversion, and the coefficient $\lambda$ is a function of the model's underlying parameters. I call the first term of equation (1a) the risk component and the second term the hedge component. It is well known that stock market variance is serially correlated in the data; also, there is no particular reason to believe that the covariance between excess

\footnotetext{
3 A simple model developed by Guo (2001) makes this point clear. If the conditional stock market return is proportional to the risk, the author shows that excess stock market return is positively correlated with lagged stock market variance and is negatively correlated with current variance. Given that stock market variance is negatively correlated with future output, the positive relation between excess return and lagged variance weakens the forecasting power of the former. His model, therefore, explains why stock market variance drives out return in forecasting GDP growth, as documented by Campbell et al. (2001).

4 The stochastically detrended risk-free rate is the risk-free rate less its average over the last four quarters.

5 Lettau and Ludvigson (2001a) find that the dividend yield loses its forecasting ability when the sample period is extended to the later 1990 s, a result I reproduce later in the paper.
} 


\section{Table 1}

\section{Forecasting Quarterly Excess Stock Market Return}

\begin{tabular}{|c|c|c|c|c|c|c|}
\hline Row & $\mathbf{e}_{M, t}$ & $d p_{t}$ & rrel $_{t}$ & cay $_{t}$ & $\sigma_{M, t}^{2}$ & $\overline{\mathbf{R}}^{2}$ \\
\hline 1 & $\begin{array}{c}0.065 \\
(1.054)\end{array}$ & & & & & -0.00 \\
\hline 2 & & $\begin{array}{c}0.009 \\
(1.459)\end{array}$ & & & & 0.01 \\
\hline 3 & & & $\begin{array}{c}-0.020 \\
(-3.929)\end{array}$ & & & 0.07 \\
\hline 4 & & & & $\begin{array}{c}1.931 \\
(3.211)\end{array}$ & & 0.08 \\
\hline 5 & & & & & $\begin{array}{c}4.601 \\
(2.825)\end{array}$ & 0.03 \\
\hline 6 & $\begin{array}{c}-0.083 \\
(-1.658)\end{array}$ & $\begin{array}{c}0.002 \\
(0.254)\end{array}$ & $\begin{array}{c}-0.018 \\
(-4.783)\end{array}$ & $\begin{array}{c}1.784 \\
(3.861)\end{array}$ & & 0.12 \\
\hline 7 & $\begin{array}{c}0.029 \\
(0.569)\end{array}$ & $\begin{array}{c}0.002 \\
(0.537)\end{array}$ & $\begin{array}{l}-0.014 \\
(-4.030)\end{array}$ & $\begin{array}{c}2.333 \\
(5.579)\end{array}$ & $\begin{array}{c}7.391 \\
(5.249)\end{array}$ & 0.20 \\
\hline
\end{tabular}

NOTE: This table reports the ordinary least-squares (OLS) regression results of excess stock market return, $\mathrm{e}_{M, t+1}$, on informational variables, including the lagged excess stock market return, $\mathrm{e}_{M, t} ;$ the dividend yield, $d p_{t} ;$ the stochastically detrended risk-free rate, $r$ rel ${ }_{t} ;$ the consumption-wealth ratio, cay ${ }_{t} ;$ and the realized stock market variance, $\sigma_{M, t}^{2}$. Newey-West (1987) corrected standard errors are used to calculate the $t$ statistics, which are reported in parentheses. The data are quarterly and span from 1953:Q1 to 2000:Q4. See Appendix A for a description of the data.

stock market returns and investment opportunities is constant or that its coefficient is zero. In general, the expected stock market return is not constant and stock market returns are predictable.

While the early literature has emphasized the risk component, Guo (2000) shows that the hedge component is also important in understanding the time-varying equity premium in a limited stock market participation model. As shown in equation (1b), the equity premium also has two components in the model developed by Guo (2000)6:

(1b)

$E_{t} e_{M, t+1}+E_{t} \frac{\sigma_{M, t+1}^{2}}{2} \approx \gamma E_{t} \sigma_{M C, t+1}+r_{1, t+1}^{f}-\min \left\{r_{1, t+1}^{f}, r_{2, t+1}^{f}\right\}$,

where $E_{t} \sigma_{M C, t+1}$ is the covariance between the shareholder's consumption growth and stock market returns and $r_{1, t+1}^{f}$ and $r_{2, t+1}^{f}$ are the shareholder's and the non-shareholder's shadow risk-free rates, respectively. While the first term, $\gamma E_{t} \sigma_{M C, t+1}$, is proportional to the risk component in equation (1a), the second term, $r_{1, t+1}^{f}-\min \left\{r_{1, t+1}^{f}, r_{2, t+1}^{f}\right\}$, can be thought of as a liquidity premium because it reflects the fact that the shareholder cannot use stocks to hedge the income risks because of the constraints of limited stock market participation. Moreover, such a liquidity premium is small (large) when the stock price is high (low); therefore, it is positively correlated with the dividend yield. Interestingly, Guo (2000) also predicts that, when the dividend yield is low, stock market variance should be negatively correlated with the dividend yield. Thus, given that the consumption-wealth ratio is equivalent to the dividend yield in Guo (2000), his model well explains the empirical evidence documented in Table $1 .{ }^{7}$

${ }^{6}$ The variance term

$$
E_{t} \frac{\sigma_{M, t+1}^{2}}{2}
$$

on the left-hand side of equation (1b) is the adjustment for Jensen's inequality.

7 Campbell, Lo, and MacKinlay (1997) explain that the dividend yield forecasts stock market returns because it can be written as a function of expected future excess stock market return and dividend growth. Similarly, Lettau and Ludvigson (2001a) show that the consumptionwealth ratio is also a function of expected future excess stock market return and consumption growth. The two variables, therefore, are equivalent in an exchange economy (e.g., Guo, 2000). Despite their close theoretical link, the consumption-wealth ratio demonstrates much stronger predictive power than the dividend yield does, possibly because the former is a better measure of its theoretical counterpart than the latter is. 


\section{A DECOMPOSITION OF EXCESS STOCK MARKET RETURN}

Given strong evidence of stock return predictability, in this section, I adopt Campbell and Shiller's (1988) log-linearization method to decompose excess stock market return into three parts: expected return, a shock to the expected future return, and a shock to the expected future dividend growth. The advantages of this approach are tractability and accuracy.

The continuously compounded stock market return, $r_{M, t}$, is defined as

$$
r_{M, t}=\log \left(P_{M, t}+D_{M, t}\right)-\log \left(P_{M, t-1}\right),
$$

where $P_{M, t}$ is the stock price at the end of period $t$ and $D_{M, t}$ is the dividend paid out during period $t$. Throughout this paper, I use upper case to denote the level and lower case to denote the log. Using a first-order Taylor expansion around the steady state of the log dividend price ratio $\overline{d-p}$, equation (2) can be rewritten as a first-order difference equation for the stock price:

$$
r_{M, t} \approx k+\rho p_{M, t}-p_{M, t-1}+(1-\rho) d_{M, t},
$$

where

$$
\begin{gathered}
\rho=\frac{1}{1+\exp (\overline{d-p)},} \\
k=-\log (\rho)-(1-\rho) \log \left(\frac{1}{\rho}-1\right) .
\end{gathered}
$$

Campbell, Lo, and MacKinlay (1997) report that the annual dividend yield is about 4 percent in the historical data. Accordingly, I set $\rho$ to 0.99 for the quarterly data in this paper.

Solving equation (3) forward and imposing the transversality condition

$$
\lim _{j \rightarrow \infty} \rho^{j} P_{M, t+j}=0,
$$

the stock price can be written as a function of future dividend flows and discount rates:

$$
p_{M, t-1}=\frac{k}{1-\rho}+\sum_{j=0}^{\infty} \rho^{j}\left[(1-\rho) d_{M, t+j}-r_{M, t+j}\right] .
$$

Equation (4) is simply an accounting identity, which also holds ex ante:

$$
p_{M, t-1}=\frac{k}{1-\rho}+E_{t} \sum_{j=0}^{\infty} \rho^{j}\left[(1-\rho) d_{M, t+j}-r_{M, t+j}\right] .
$$

Substituting equation (5) into equation (3), I then decompose the realized excess stock market return into three parts: expected return, a shock to the expected future dividend growth, and a shock to the expected future return.

$$
\begin{aligned}
& r_{M, t}-E_{t-1} r_{M, t}= \\
& \left(E_{t}-E_{t-1}\right) \sum_{j=0}^{\infty} \rho^{j} \Delta d_{M, t+j}-\left(E_{t}-E_{t-1}\right) \sum_{j=1}^{\infty} \rho^{j} r_{M, t+j} .
\end{aligned}
$$

For the excess stock market return, $e_{M, t+1}=$ $r_{M, t+1}-r_{f, t+1}$, where $r_{f, t+1}$ is the real risk-free rate, I can rewrite equation (6) as

(7)

$$
\begin{aligned}
& e_{M, t}-E_{t-1} e_{M, t}= \\
& \left(E_{t}-E_{t-1}\right)\left(\sum_{j=0}^{\infty} \rho^{j} \Delta d_{M, t+j}-\sum_{j=0}^{\infty} \rho^{j} r_{f, t+j}-\sum_{j=1}^{\infty} \rho^{j} e_{M, t+j}\right) .
\end{aligned}
$$

I assume that, $x_{1, t}, x_{2, t}, \ldots x_{n, t}$ are $n$ state variables that predict excess stock market return, and the vector $X_{t}=\left[e_{M, t}, x_{1, t}, x_{2, t}, \ldots x_{n, t}\right]$ follows a first order vector autoregression (VAR) process

$$
X_{t}=A+B X_{t-1}+\varepsilon_{t},
$$

where $A$ is an $(n+1)$ by 1 vector of constants, $B$ is an $(n+1)$ by $(n+1)$ coefficient matrix, and $\varepsilon_{t}$ is an $(n+1)$ by 1 vector of white noise. Then, the expected excess stock market return, $E_{t-1} e_{m, t}$, is equal to $e 1^{\prime} B_{1} X_{1}$, where $e 1$ is an $n$ by 1 vector $[1,0, \ldots, 0]$. As shown in Appendix B, the shock to the expected future return,

$$
-\left(E_{t}-E_{t-1}\right) \sum_{j=1}^{\infty} \rho^{j} e_{M, t+j}
$$

is equal to $e 1^{\prime} \rho B(I-\rho B)^{-1} \varepsilon_{t}$, where $I$ is an $(n+1)$ by $(n+1)$ identity matrix. Campbell and Ammer (1993) find that the shock to the expected future real riskfree rate,

$$
-\left(E_{t}-E_{t-1}\right) \sum_{j=0}^{\infty} \rho^{j} r_{f, t+j},
$$

accounts for very few variations in excess stock market return. For simplicity, I assume that its value is zero; and therefore, the shock to the expected future dividend growth,

$$
\left(E_{t}-E_{t-1}\right) \sum_{j=0}^{\infty} \rho^{j} \Delta d_{M, t+j},
$$

is approximately equal to $e_{M, t}-E_{t-1} e_{M, t}-e 1^{\prime} \rho B$ $(I-\rho B)^{-1} \varepsilon_{t}$. Furthermore, I denote the shock to the expected future return,

$$
-\left(E_{t}-E_{t-1}\right) \sum_{j=1}^{\infty} \rho^{j} e_{M, t+j},
$$




\section{Table 2}

Vector Autoregression of Excess Stock Market Return

\begin{tabular}{|c|c|c|c|c|c|c|}
\hline & $\mathbf{e}_{M, t}$ & $d p_{t}$ & rrel $_{t}$ & cay $_{t}$ & $\sigma_{M, t}^{2}$ & $\overline{\mathbf{R}}^{2}$ \\
\hline$e_{M, t+1}$ & $\begin{array}{c}0.029 \\
(0.569)\end{array}$ & $\begin{array}{c}0.002 \\
(0.537)\end{array}$ & $\begin{array}{c}-0.014 \\
(-4.030)\end{array}$ & $\begin{array}{c}2.333 \\
(5.579)\end{array}$ & $\begin{array}{c}7.391 \\
(5.249)\end{array}$ & 0.20 \\
\hline$d p_{t+1}$ & $\begin{array}{c}-0.461 \\
(-2.183)\end{array}$ & $\begin{array}{c}0.980 \\
(76.929)\end{array}$ & $\begin{array}{c}0.061 \\
(5.130)\end{array}$ & $\begin{array}{l}-5.544 \\
(-4.191)\end{array}$ & $\begin{array}{c}-24.104 \\
(-5.894)\end{array}$ & 0.95 \\
\hline rrel $_{t+1}$ & $\begin{array}{c}0.753 \\
(0.975)\end{array}$ & $\begin{array}{c}-0.083 \\
(-1.216)\end{array}$ & $\begin{array}{c}0.706 \\
(14.113)\end{array}$ & $\begin{array}{c}-8.381 \\
(-1.529)\end{array}$ & $\begin{array}{c}-25.995 \\
(-1.421)\end{array}$ & 0.51 \\
\hline cay $_{t+1}$ & $\begin{array}{c}-0.050 \\
(-6.911)\end{array}$ & $\begin{array}{c}0.001 \\
(1.559)\end{array}$ & $\begin{array}{c}-0.001 \\
(-1.684)\end{array}$ & $\begin{array}{c}0.926 \\
(25.903)\end{array}$ & $\begin{array}{c}0.184 \\
(1.668)\end{array}$ & 0.80 \\
\hline$\sigma_{M, t+1}^{2}$ & $\begin{array}{c}0.004 \\
(1.400)\end{array}$ & $\begin{array}{l}-0.000 \\
(-0.880)\end{array}$ & $\begin{array}{c}0.000 \\
(0.929)\end{array}$ & $\begin{array}{c}-0.078 \\
(-2.930)\end{array}$ & $\begin{array}{c}0.388 \\
(5.274)\end{array}$ & 0.24 \\
\hline
\end{tabular}

NOTE: This table reports the ordinary least-squares (OLS) regression results of the VAR system specified by equation (8). Newey-West (1987) corrected standard errors are used to calculate the t statistics, which are reported in parentheses. The data are quarterly and span from 1953:Q1 to 2000:Q4. See Appendix A for a description of the data.

\section{Table 3}

\section{Summary Statistics}

\begin{tabular}{lcccc} 
& $\mathbf{e}_{\boldsymbol{M}, \boldsymbol{t}}$ & $\boldsymbol{E}_{\boldsymbol{t}-\mathbf{1}} \mathbf{e}_{\boldsymbol{M}, \boldsymbol{t}}$ & $\eta_{\mathbf{e}, \boldsymbol{t}}$ & \\
\hline Panel A: Mean and standard error & & & & \\
Mean & 0.074 & 0.074 & 0.000 & 0.000 \\
Standard error & 0.324 & 0.151 & 0.278 & 0.147 \\
Panel B: Covariance and correlation & & & \\
$e_{M, t}$ & $\mathbf{0 . 1 0 5}$ & 0.47 & 0.76 \\
$E_{t-1} e_{M, t}$ & $\mathbf{0 . 0 2 3}$ & $\mathbf{0 . 0 2 3}$ & 0.00 & 0.27 \\
$\eta_{e, t}$ & $\mathbf{0 . 0 6 9}$ & $\mathbf{0 . 0 0 0}$ & $\mathbf{0 . 0 7 7}$ & -0.21 \\
$\eta_{d, t}$ & $\mathbf{0 . 0 1 3}$ & $\mathbf{0 . 0 0 0}$ & $\mathbf{- 0 . 0 0 9}$ & $\mathbf{0 . 0 2 2}$
\end{tabular}

NOTE: This table reports the mean, standard error, covariance (lower triangle of Panel B, in bold), and correlation (upper triangle of Panel B) of the excess stock market return in its three components. The decomposition is based on the VAR estimation reported in Table 2 .

by $\eta_{e, t}$ and the shock to the expected future dividend growth,

$$
\left(E_{t}-E_{t-1}\right) \sum_{j=0}^{\infty} \rho^{j} \Delta d_{M, t+j},
$$

by $\eta_{d, t}$. Note, $\eta_{e, t}$ and $\eta_{d, t}$ are orthogonal to $E_{t-1} e_{M, t}$ by definition.

Table 2 reports the ordinary least-squares (OLS) estimate of the VAR system specified in equation (8). The state variables include all the forecasting variables used in Table 1. I adopt a VAR (1) specification because it is consistent with the Schwarz
Bayesian information criterion and the Akaike information criterion. One interesting observation is that the coefficient on its own lag is pretty large for $d p_{t}$, $\mathrm{rrel}_{t}$, and cay , whereas it is only 0.38 for $\sigma_{M, t}^{2}$. Therefore, unlike other forecasting variables, $\sigma_{M, t}^{2}$ captures relatively high-frequency variations in excess stock market return.

Summary statistics for excess stock market return, $e_{M, t}$, and its three components are reported in Table 3. By construction, shocks to the expected future return, $\eta_{e, t}$, and shocks to the expected future dividend growth, $\eta_{d, t}$, both have zero means. How- 


\section{Figure 1}

\section{Realized Excess Stock Market Return}

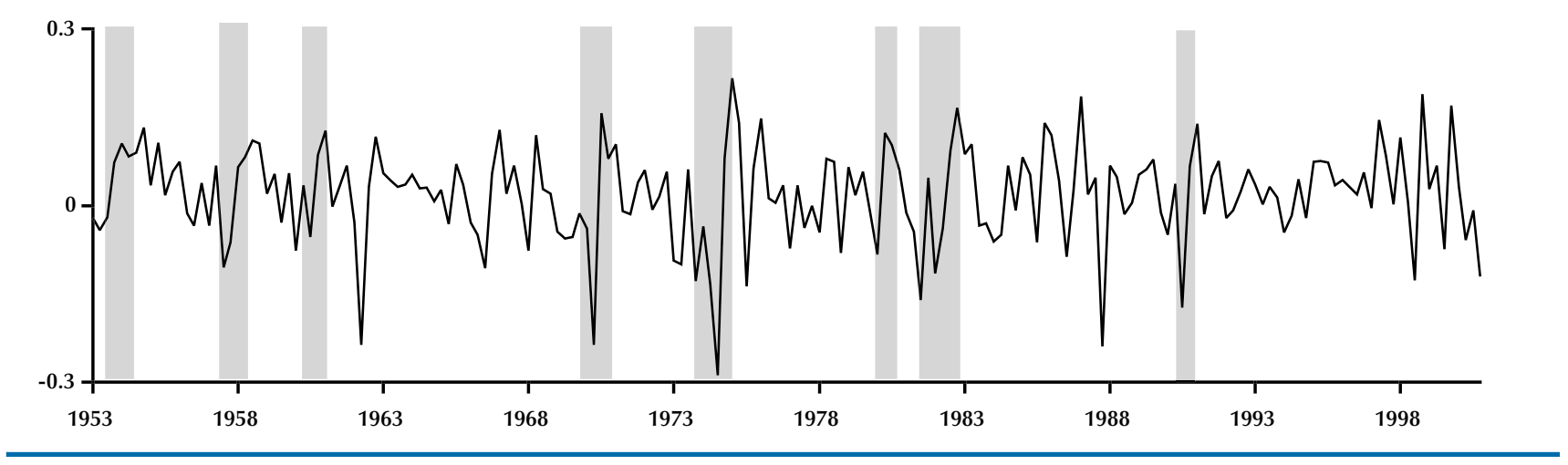

\section{Figure 2}

\section{Expected Excess Stock Market Return}

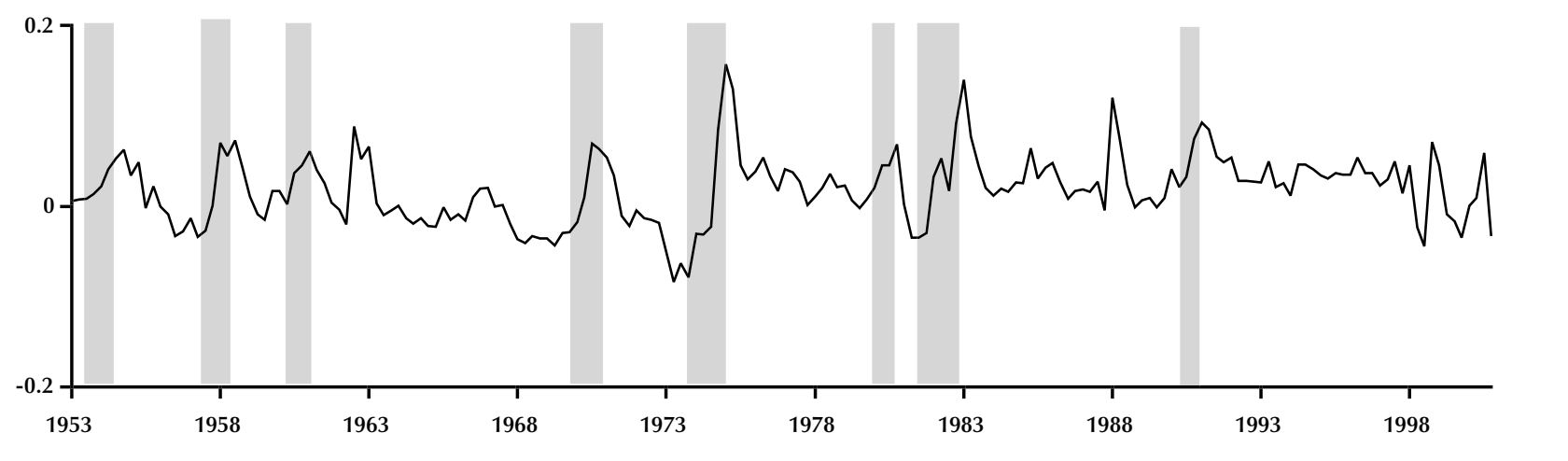

ever, the standard error of $\eta_{e, t}$ is almost twice as large as that of $\eta_{d, t}$. The expected return, $E_{t-1} e_{M, t}$, has the same mean as, but a much smaller standard error than, that of $e_{M, t}$. Moreover, the covariance between $\eta_{e, t}$ and $e_{M, t}$ is about 66 percent of the variance of $e_{M, t}$, while it is 22 percent for $E_{t-1} e_{M, t}$ and 12 percent for $\eta_{d, t}$. Similarly, $\eta_{e, t}$ has the largest correlation coefficient with $e_{M, t}$, followed by $E_{t-1} e_{M, t}$ and $\eta_{d, t}$. Therefore, $\eta_{e, t}$ and $E_{t-1} e_{M, t}$ account for the vast majority of variations in $e_{M, t}$, while $\eta_{d, t}$ is relatively unimportant in explaining stock price movements. In other words, stock price is not sensitive to the dividend news. My results are consistent with those reported in the early literature (e.g., Campbell and Shiller, 1988), although the two papers adopt different forecasting variables.

Figures 1 through 4 plot excess stock market return and its three components, with the shaded areas indicating recessions, the dates of which were determined by the National Bureau of Economic Research. Figure 1 shows that stock price seems to decrease (increase) at the beginning (end) of recessions. However, it fluctuates dramatically over time and displays little business cycle pattern. This assessment is consistent with the conventional skepticism about stock price as a leading indicator. The picture is quite different for the expected return. Figure 2 shows that the expected return always increases during recessions and decreases during expansions. In only two occasions, namely, the second quarter of 1962 and the fourth quarter of 1987, were the sharp increases in the expected return not associated with recessions. In the first case, the economy slowed down significantly in the following quarters. In the second case, the expected return was driven up solely by the dramatic increase in stock market 


\section{Figure 3}

\section{Shock to the Expected Future Return}

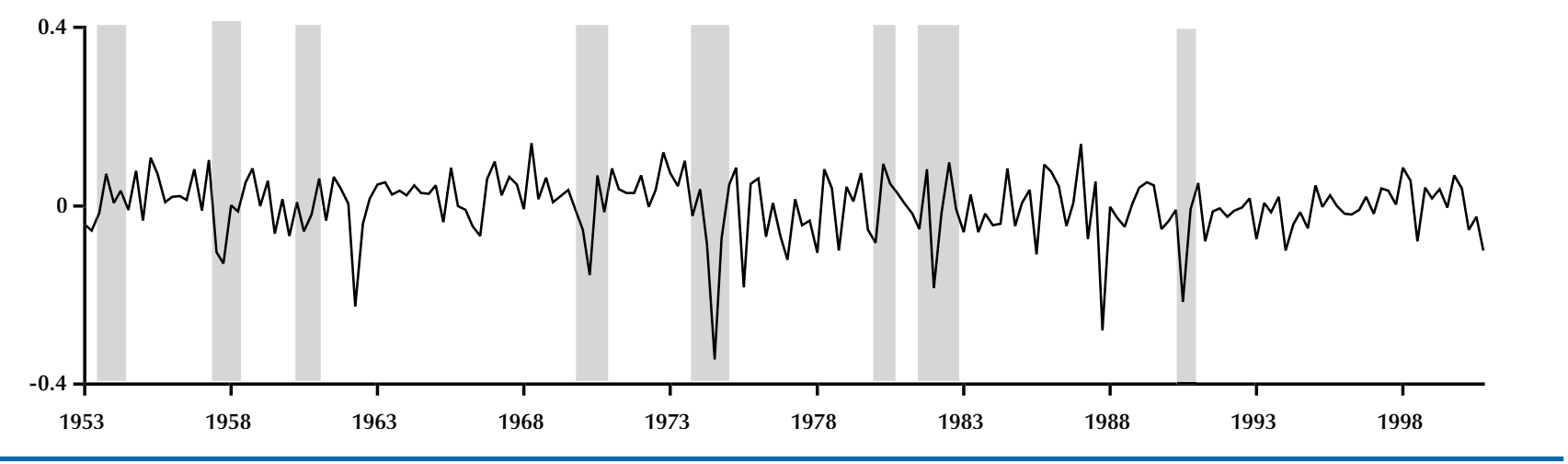

\section{Figure 4}

\section{Shock to the Expected Future Dividend Growth}

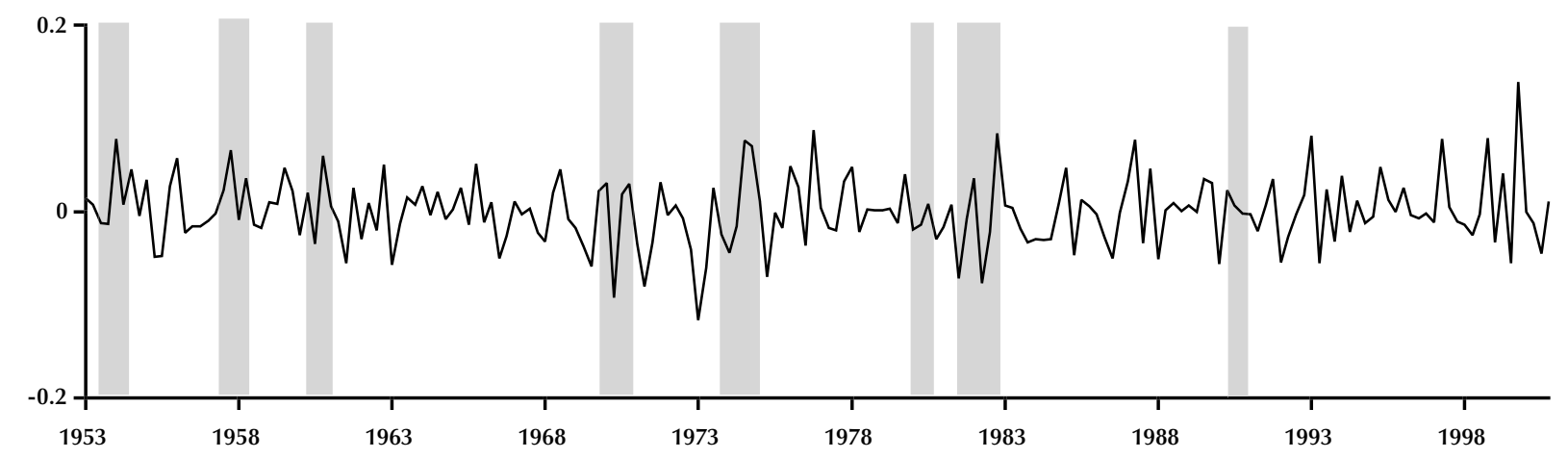

variance because of the October 19, 1987, stock market crash, which was unusual and short-lived. My findings of a strongly cyclical expected return should not be a surprise because forecasting variables such as the consumption-wealth ratio, the stochastically detrended risk-free rate, and past stock market variance all display strong business cycle patterns. In contrast, Figures 3 and 4 show that shocks to the expected future return and shocks to the expected future dividend growth do not move in tandem very much with business cycles.

\section{STOCK MARKET RETURNS AND FUTURE ECONOMIC ACTIVITIES}

Excess stock market return, $e_{M, t}$, is high because (i) it is expected to be high or $E_{t-1} e_{M, t}$ is high, (ii) there is a negative shock to the expected future return or $\eta_{e, t}$ is high, or (iii) there is a positive shock to the expected future dividend growth or $\eta_{d, t}$ is high. In this section, I analyze the relative importance of these components in forecasting economic activities.

\section{Fixed Private Nonresidential Investment}

Table 4 reports the long-horizon regression results of the fixed private nonresidential investment growth on excess stock market return and its three components. ${ }^{8}$ For horizon $H$, the dependent variable is the investment growth rate from time $t+1$ to $t+1+H$. Row 1 shows that excess stock market return, $e_{M, t}$, is always positively correlated with future investment growth. Its predictive power as measured by the adjusted $R^{2}$ first increases then decreases and peaks at four quarters, at which it

8 I obtain qualitatively similar results if I also include the lagged dependent variable as a regressor. 


\section{Table 4}

\section{Forecasting Fixed Nonresidential Investment Growth}

\begin{tabular}{|c|c|c|c|c|c|c|c|}
\hline \multirow[b]{2}{*}{ Row } & \multirow[b]{2}{*}{ Regressor } & \multicolumn{6}{|c|}{ Forecast horizon } \\
\hline & & 1 & 2 & 4 & 8 & 12 & 16 \\
\hline 1 & $e_{M, t}$ & $\begin{array}{c}0.01 \\
(0.40) \\
{[0.00]}\end{array}$ & $\begin{array}{c}0.11 \\
(2.82) \\
{[0.04]}\end{array}$ & $\begin{array}{c}0.26 \\
(3.41) \\
{[0.08]}\end{array}$ & $\begin{array}{c}0.33 \\
(3.25) \\
{[0.06]}\end{array}$ & $\begin{array}{c}0.24 \\
(2.60) \\
{[0.02]}\end{array}$ & $\begin{array}{c}0.13 \\
(1.21) \\
{[0.00]}\end{array}$ \\
\hline 2 & $E_{t-1} e_{M, t}$ & $\begin{array}{r}-0.09 \\
(-2.20) \\
{[0.02]}\end{array}$ & $\begin{array}{l}-0.01 \\
(-0.14) \\
{[-0.00]}\end{array}$ & $\begin{array}{c}0.38 \\
(1.77) \\
{[0.04]}\end{array}$ & $\begin{array}{l}1.05 \\
(3.72) \\
{[0.14]}\end{array}$ & $\begin{array}{c}1.20 \\
(4.21) \\
{[0.14]}\end{array}$ & $\begin{array}{l}1.09 \\
(3.08) \\
{[0.09]}\end{array}$ \\
\hline 3 & $\eta_{e, t}$ & $\begin{array}{c}0.06 \\
(1.62) \\
{[0.02]}\end{array}$ & $\begin{array}{c}0.15 \\
(2.59) \\
{[0.07]}\end{array}$ & $\begin{array}{c}0.20 \\
(2.26) \\
{[0.03]}\end{array}$ & $\begin{array}{c}0.03 \\
(0.35) \\
{[-0.01]}\end{array}$ & $\begin{array}{l}-0.12 \\
(-1.11) \\
{[-0.00]}\end{array}$ & $\begin{array}{r}-0.21 \\
(-1.67) \\
{[0.01]}\end{array}$ \\
\hline 4 & $\eta_{d, t}$ & $\begin{array}{r}-0.08 \\
(-1.18) \\
{[0.01]}\end{array}$ & $\begin{array}{l}-0.05 \\
(-0.42) \\
{[-0.00]}\end{array}$ & $\begin{array}{c}0.10 \\
(0.76) \\
{[-0.00]}\end{array}$ & $\begin{array}{c}0.33 \\
(2.12) \\
{[0.01]}\end{array}$ & $\begin{array}{c}0.31 \\
(1.67) \\
{[0.00]}\end{array}$ & $\begin{array}{r}0.23 \\
(1.08) \\
{[-0.00]}\end{array}$ \\
\hline 5 & $\eta_{e, t}+\eta_{d, t}$ & $\begin{array}{c}0.04 \\
(1.42) \\
{[0.01]}\end{array}$ & $\begin{array}{c}0.14 \\
(2.92) \\
{[0.05]}\end{array}$ & $\begin{array}{c}0.22 \\
(2.75) \\
{[0.05]}\end{array}$ & $\begin{array}{c}0.12 \\
(1.23) \\
{[0.00]}\end{array}$ & $\begin{array}{l}-0.04 \\
(-0.48) \\
{[-0.01]}\end{array}$ & $\begin{array}{r}-0.15 \\
(-1.34) \\
{[0.00]}\end{array}$ \\
\hline 6 & $E_{t-1} e_{M, t}$ & $\begin{array}{c}-0.09 \\
(-2.09)\end{array}$ & $\begin{array}{c}-0.01 \\
(-0.09)\end{array}$ & $\begin{array}{c}0.38 \\
(1.83)\end{array}$ & $\begin{array}{c}1.04 \\
(3.89)\end{array}$ & $\begin{array}{c}1.19 \\
(4.40)\end{array}$ & $\begin{array}{c}1.08 \\
(3.07)\end{array}$ \\
\hline & $\eta_{e, t}$ & $\begin{array}{c}0.05 \\
(1.58)\end{array}$ & $\begin{array}{c}0.16 \\
(2.80)\end{array}$ & $\begin{array}{c}0.23 \\
(2.56)\end{array}$ & $\begin{array}{c}0.09 \\
(0.91)\end{array}$ & $\begin{array}{c}-0.07 \\
(-0.74)\end{array}$ & $\begin{array}{l}-0.18 \\
(-1.45)\end{array}$ \\
\hline & $\eta_{d, t}$ & $\begin{array}{r}-0.05 \\
(-0.97) \\
{[0.04]}\end{array}$ & $\begin{array}{c}0.04 \\
(0.47) \\
{[0.05]}\end{array}$ & $\begin{array}{c}0.21 \\
(1.87) \\
{[0.08]}\end{array}$ & $\begin{array}{c}0.36 \\
(2.47) \\
{[0.15]}\end{array}$ & $\begin{array}{c}0.25 \\
(1.65) \\
{[0.13]}\end{array}$ & $\begin{array}{c}0.12 \\
(0.60) \\
{[0.09]}\end{array}$ \\
\hline & $L R$ & 9.39 & 4.70 & 1.06 & 19.18 & 24.05 & 18.59 \\
\hline
\end{tabular}

NOTE: This table reports the ordinary least-squares (OLS) regression results of real fixed nonresidential investment growth on excess stock market return and its three components. Newey-West (1987) corrected standard errors are used to calculate the $t$ statistics, which are reported in parentheses. The adjusted $R^{2}$ is reported in brackets. $L R$, the statistic of log-likelihood ratio test of equal coefficients in row 6 , has a $\chi^{2}$ distribution with two degrees of freedom and its critical value at the 5 percent significance level is 5.99 . The data are quarterly and span from 1953:Q1 to 1997:Q4 because of the leads in the dependent variable. The decomposition is based on the VAR estimation reported in Table 2. See Appendix A for a description of the data.

explains 8 percent of variations in future investment growth. In row 2 , the expected return, $E_{t-1} e_{M, t}$, is negatively correlated with the next two quarters' investment growth and the correlation turns positive as the forecasting horizon increases. Its predictive power concentrates at relatively long horizons and peaks around two to three years, at which it explains about 14 percent of variations in investment growth. As shown in row 3, shocks to the expected future return, $\eta_{e, t}$, also forecast investment growth; however, their predictive patterns are quite different from those of $E_{t-1} e_{M, t}$. In particular, $\eta_{e, t}$ is positively correlated with future investment growth over short horizons and the correlation turns negative as the forecasting horizon increases. Moreover, its predic- tive power concentrates at relatively short horizons and peaks at two quarters, at which it explains about 7 percent of variations in investment growth. In contrast, row 4 shows that the shock to the dividend, $\eta_{d, t}$, does not contain much information about future investment growth. The correlation between the two is not statistically significant until the forecasting horizon increases to 2 years, and then it becomes insignificant again at longer forecasting horizons. At its peak, $\eta_{d, t}$ explains only 1 percent of variations in the investment growth rate. Moreover, row 5 shows that the total shock, $\eta_{e, t}+\eta_{d, t}$, displays a similar predictive pattern to that of $\eta_{e, t}$. Therefore, the forecasting power of stock market return mainly comes from the expected return and shocks to the expected 


\section{Table 5}

\section{Forecasting Nondurable Consumption and Service Growth}

\begin{tabular}{|c|c|c|c|c|c|c|c|}
\hline \multirow[b]{2}{*}{ Row } & \multirow[b]{2}{*}{ Regressor } & \multicolumn{6}{|c|}{ Forecast horizon } \\
\hline & & 1 & 2 & 4 & 8 & 12 & 16 \\
\hline 1 & $e_{M, t}$ & $\begin{array}{c}0.01 \\
(2.60) \\
{[0.05]}\end{array}$ & $\begin{array}{c}0.02 \\
(2.56) \\
{[0.05]}\end{array}$ & $\begin{array}{c}0.04 \\
(3.27) \\
{[0.05]}\end{array}$ & $\begin{array}{c}0.03 \\
(2.14) \\
{[0.01]}\end{array}$ & $\begin{array}{c}0.03 \\
(1.83) \\
{[0.00]}\end{array}$ & $\begin{array}{r}0.02 \\
(1.10) \\
{[-0.00]}\end{array}$ \\
\hline 2 & $E_{t-1} e_{M, t}$ & $\begin{array}{c}0.00 \\
(0.27) \\
{[-0.00]}\end{array}$ & $\begin{array}{c}0.02 \\
(0.59) \\
{[0.00]}\end{array}$ & $\begin{array}{c}0.04 \\
(0.73) \\
{[0.01]}\end{array}$ & $\begin{array}{c}0.06 \\
(0.77) \\
{[0.01]}\end{array}$ & $\begin{array}{c}0.01 \\
(0.11) \\
{[-0.01]}\end{array}$ & $\begin{array}{l}-0.06 \\
(-0.58) \\
{[-0.00]}\end{array}$ \\
\hline 3 & $\eta_{e, t}$ & $\begin{array}{c}0.02 \\
(3.04) \\
{[0.07]}\end{array}$ & $\begin{array}{c}0.03 \\
(2.67) \\
{[0.05]}\end{array}$ & $\begin{array}{c}0.03 \\
(1.97) \\
{[0.03]}\end{array}$ & $\begin{array}{c}0.01 \\
(0.49) \\
{[-0.00]}\end{array}$ & $\begin{array}{c}0.03 \\
(0.93) \\
{[-0.00]}\end{array}$ & $\begin{array}{c}0.04 \\
(1.23) \\
{[0.00]}\end{array}$ \\
\hline 4 & $\eta_{d, t}$ & $\begin{array}{c}-0.01 \\
(-0.72) \\
{[-0.00]}\end{array}$ & $\begin{array}{c}-0.01 \\
(-0.68) \\
{[-0.00]}\end{array}$ & $\begin{array}{c}0.02 \\
(0.94) \\
{[-0.00]}\end{array}$ & $\begin{array}{c}0.03 \\
(0.71) \\
{[-0.00]}\end{array}$ & $\begin{array}{c}0.01 \\
(0.24) \\
{[-0.01]}\end{array}$ & $\begin{array}{l}-0.02 \\
(-0.42) \\
{[-0.01]}\end{array}$ \\
\hline 5 & $\eta_{e, t}+\eta_{d, t}$ & $\begin{array}{c}0.02 \\
(2.76) \\
{[0.06]}\end{array}$ & $\begin{array}{c}0.02 \\
(2.51) \\
{[0.04]}\end{array}$ & $\begin{array}{c}0.04 \\
(2.66) \\
{[0.04]}\end{array}$ & $\begin{array}{c}0.02 \\
(0.96) \\
{[-0.00]}\end{array}$ & $\begin{array}{c}0.03 \\
(1.14) \\
{[0.00]}\end{array}$ & $\begin{array}{c}0.04 \\
(1.26) \\
{[0.00]}\end{array}$ \\
\hline 6 & $E_{t-1} e_{M, t}$ & $\begin{array}{c}0.0 \\
(0.33)\end{array}$ & $\begin{array}{c}0.02 \\
(0.64)\end{array}$ & $\begin{array}{c}0.04 \\
(0.79)\end{array}$ & $\begin{array}{c}0.06 \\
(0.81)\end{array}$ & $\begin{array}{c}0.01 \\
(0.12)\end{array}$ & $\begin{array}{l}-0.06 \\
(-0.58)\end{array}$ \\
\hline & $\eta_{e, t}$ & $\begin{array}{c}0.02 \\
(2.92)\end{array}$ & $\begin{array}{c}0.03 \\
(2.58)\end{array}$ & $\begin{array}{c}0.04 \\
(2.41)\end{array}$ & $\begin{array}{c}0.02 \\
(0.76)\end{array}$ & $\begin{array}{c}0.03 \\
(1.07)\end{array}$ & $\begin{array}{c}0.04 \\
(1.30)\end{array}$ \\
\hline & $\eta_{d, t}$ & $\begin{array}{c}0.00 \\
(0.41) \\
{[0.06]}\end{array}$ & $\begin{array}{c}0.00 \\
(0.34) \\
{[0.05]}\end{array}$ & $\begin{array}{c}0.04 \\
(1.68) \\
{[0.04]}\end{array}$ & $\begin{array}{c}0.04 \\
(1.01) \\
{[0.00]}\end{array}$ & $\begin{array}{c}0.03 \\
(0.65) \\
{[-0.01]}\end{array}$ & $\begin{array}{c}0.01 \\
(0.11) \\
{[-0.00]}\end{array}$ \\
\hline & $L R$ & 3.54 & 1.86 & 0.04 & 0.89 & 0.14 & 2.18 \\
\hline
\end{tabular}

NOTE: This table reports the ordinary least-squares (OLS) regression results of real nondurable consumption growth, which is measured by (nondurable + service - shoes - clothes), on excess stock market return and its three components. Newey-West (1987) corrected standard errors are used to calculate the $t$ statistics, which are reported in parentheses. The adjusted $\mathrm{R}^{2}$ is reported in brackets. $L R$, the statistic of log-likelihood ratio test of equal coefficients in row 6 , has a $\chi^{2}$ distribution with two degrees of freedom and its critical value at the 5 percent significance level is 5.99. The data are quarterly and span from 1953:Q1 to 1997:Q4 because of the leads in the dependent variable. The decomposition is based on the VAR estimation reported in Table 2. See Appendix A for a description of the data.

future return, while the information content of dividend shocks is rather limited. These results are not a surprise because dividend shocks account for a relatively small portion of variations in excess stock market returns, as shown in Table 3.

Although excess stock market return and future investment growth are positively correlated at all horizons, the forecasting ability of excess stock market return is considerably compromised because of different predictive patterns between the expected return and shocks to the expected future return. This point is clearly demonstrated in row 6 of Table 4, which shows the multivariate regression results of investment growth on the three components of excess stock market return. I find that the coefficients of the expected return and shocks to the expected future return have opposite signs over both short and long horizons, as in the univariate regressions. Also, the adjusted $R^{2}$ in row 6 is much higher than its counterpart in row 1 . Moreover, the last line of row 6 reports the log-likelihood ratio test of the null hypothesis that the three components have the same coefficient, which is overwhelmingly rejected in most cases.

To summarize, I find that the dividend shock of excess stock market return provides little information about future investment. Also, the expected return and shocks to the expected future return display quite different predictive patterns. Together, my results suggest that the forecasting power of 


\section{Table 6}

\section{Forecasting Durable Consumption Growth}

\begin{tabular}{|c|c|c|c|c|c|c|c|}
\hline \multirow[b]{2}{*}{ Row } & \multirow[b]{2}{*}{ Regressor } & \multicolumn{6}{|c|}{ Forecast horizon } \\
\hline & & 1 & 2 & 4 & 8 & 12 & 16 \\
\hline 1 & $e_{M, t}$ & $\begin{array}{c}0.13 \\
(3.43) \\
{[0.09]}\end{array}$ & $\begin{array}{c}0.27 \\
(5.96) \\
{[0.19]}\end{array}$ & $\begin{array}{c}0.33 \\
(4.72) \\
{[0.12]}\end{array}$ & $\begin{array}{c}0.19 \\
(3.05) \\
{[0.02]}\end{array}$ & $\begin{array}{c}0.11 \\
(1.45) \\
{[-0.00]}\end{array}$ & $\begin{array}{c}0.06 \\
(0.72) \\
{[-0.00]}\end{array}$ \\
\hline 2 & $E_{t-1} e_{M, t}$ & $\begin{array}{c}0.18 \\
(2.51) \\
{[0.03]}\end{array}$ & $\begin{array}{c}0.43 \\
(3.27) \\
{[0.10]}\end{array}$ & $\begin{array}{c}0.80 \\
(3.81) \\
{[0.16]}\end{array}$ & $\begin{array}{c}1.04 \\
(4.61) \\
{[0.14]}\end{array}$ & $\begin{array}{c}0.77 \\
(3.10) \\
{[0.05]}\end{array}$ & $\begin{array}{c}0.48 \\
(1.53) \\
{[0.01]}\end{array}$ \\
\hline 3 & $\eta_{e, t}$ & $\begin{array}{c}0.12 \\
(2.63) \\
{[0.05]}\end{array}$ & $\begin{array}{c}0.19 \\
(4.08) \\
{[0.07]}\end{array}$ & $\begin{array}{c}0.11 \\
(2.09) \\
{[0.01]}\end{array}$ & $\begin{array}{c}-0.08 \\
(-0.99) \\
{[-0.00]}\end{array}$ & $\begin{array}{c}-0.08 \\
(-0.67) \\
{[-0.00]}\end{array}$ & $\begin{array}{l}-0.02 \\
(-0.13) \\
{[-0.01]}\end{array}$ \\
\hline 4 & $\eta_{d, t}$ & $\begin{array}{c}0.01 \\
(0.06) \\
{[-0.01]}\end{array}$ & $\begin{array}{c}0.11 \\
(1.12) \\
{[0.00]}\end{array}$ & $\begin{array}{c}0.33 \\
(2.30) \\
{[0.02]}\end{array}$ & $\begin{array}{c}0.09 \\
(0.42) \\
{[-0.00]}\end{array}$ & $\begin{array}{c}-0.01 \\
(-0.08) \\
{[-0.01]}\end{array}$ & $\begin{array}{l}-0.17 \\
(-0.74) \\
{[-0.00]}\end{array}$ \\
\hline 5 & $\eta_{e, t}+\eta_{d, t}$ & $\begin{array}{c}0.12 \\
(2.95) \\
{[0.05]}\end{array}$ & $\begin{array}{c}0.23 \\
(4.88) \\
{[0.10]}\end{array}$ & $\begin{array}{c}0.19 \\
(3.25) \\
{[0.03]}\end{array}$ & $\begin{array}{c}-0.06 \\
(-0.92) \\
{[-0.00]}\end{array}$ & $\begin{array}{l}-0.09 \\
(-0.79) \\
{[-0.00]}\end{array}$ & $\begin{array}{l}-0.06 \\
(-0.52) \\
{[-0.00]}\end{array}$ \\
\hline 6 & $E_{t-1} e_{M, t}$ & $\begin{array}{c}0.18 \\
(2.78)\end{array}$ & $\begin{array}{c}0.43 \\
(3.73)\end{array}$ & $\begin{array}{c}0.79 \\
(4.23)\end{array}$ & $\begin{array}{c}1.04 \\
(4.69)\end{array}$ & $\begin{array}{c}0.76 \\
(3.08)\end{array}$ & $\begin{array}{c}0.49 \\
(1.52)\end{array}$ \\
\hline & $\eta_{e, t}$ & $\begin{array}{c}0.13 \\
(2.98)\end{array}$ & $\begin{array}{c}0.23 \\
(4.74)\end{array}$ & $\begin{array}{c}0.17 \\
(2.89)\end{array}$ & $\begin{array}{c}-0.07 \\
(-0.89)\end{array}$ & $\begin{array}{c}-0.08 \\
(-0.70)\end{array}$ & $\begin{array}{l}-0.04 \\
(-0.30)\end{array}$ \\
\hline & $\eta_{d, t}$ & $\begin{array}{c}0.07 \\
(0.85) \\
{[0.09]}\end{array}$ & $\begin{array}{c}0.23 \\
(2.48) \\
{[0.20]}\end{array}$ & $\begin{array}{c}0.41 \\
(2.70) \\
{[0.20]}\end{array}$ & $\begin{array}{c}0.04 \\
(0.23) \\
{[0.13]}\end{array}$ & $\begin{array}{r}-0.07 \\
(-0.40) \\
{[0.04]}\end{array}$ & $\begin{array}{r}-0.20 \\
(-0.93) \\
{[0.00]}\end{array}$ \\
\hline & $L R$ & 1.32 & 4.13 & 18.52 & 24.69 & 9.95 & 3.64 \\
\hline
\end{tabular}

NOTE: This table reports the ordinary least-squares (OLS) regression results of real durable consumption growth on excess stock market return and its three components. Newey-West (1987) corrected standard errors are used to calculate the $t$ statistics, which are reported in parentheses. The adjusted $R^{2}$ is reported in brackets. $L R$, the statistic of log-likelihood ratio test of equal coefficients in row 6 , has a $\chi^{2}$ distribution with two degrees of freedom and its critical value at the 5 percent significance level is 5.99. The data are quarterly and span from 1953:Q1 to 1997:Q4 because of the leads in the dependent variable. The decomposition is based on the VAR estimation reported in Table 2. See Appendix A for a description of the data.

excess stock market return is rather limited, although it is a forward-looking variable.

\section{Nondurable Consumption and Service}

Hall (1978) documents a positive relationship between stock price and future consumption (nondurable and service) growth, which is at odds with the permanent income hypothesis. Hall interprets his results as consumption adjusting to capital gain with lags. In row 1 of Table 5, I confirm Hall's results and show that excess stock market return, $e_{M, t}$, forecasts consumption growth up to eight quarters. ${ }^{9}$ Its predictive power peaks around four quarters with an adjusted $R^{2}$ of about 5 percent. Row 2 shows that the information content of excess stock market return does not come from the expected return, $E_{t-1} e_{M, t}$, which does not forecast consumption growth at any horizons. This finding is consistent with early evidence that consumption is not sensitive to interest rate changes or that the elasticity of inter-temporal substitution is small. Interestingly, dividend shocks, $\eta_{d, t}$, do not explain future consumption growth either, as shown in row 4 . Therefore, all the predictive power of excess stock market return comes from shocks to the expected future return, $\eta_{e, t}$. As shown in row $3, \eta_{e, t}$ forecasts con-

\footnotetext{
9 In Table 5, I exclude shoes and clothes from the nondurable consumption.
} 


\section{Table 7}

\section{Forecasting Fixed Residential Investment Growth}

\begin{tabular}{|c|c|c|c|c|c|c|c|}
\hline \multirow[b]{2}{*}{ Row } & \multirow[b]{2}{*}{ Regressor } & \multicolumn{6}{|c|}{ Forecast horizon } \\
\hline & & 1 & 2 & 4 & 8 & 12 & 16 \\
\hline 1 & $e_{M, t}$ & $\begin{array}{c}0.29 \\
(4.55) \\
{[0.20]}\end{array}$ & $\begin{array}{c}0.49 \\
(4.49) \\
{[0.19]}\end{array}$ & $\begin{array}{c}0.55 \\
(3.69) \\
{[0.09]}\end{array}$ & $\begin{array}{c}0.14 \\
(0.64) \\
{[-0.00]}\end{array}$ & $\begin{array}{c}0.04 \\
(0.24) \\
{[-0.01]}\end{array}$ & $\begin{array}{c}0.06 \\
(0.37) \\
{[-0.01]}\end{array}$ \\
\hline 2 & $E_{t-1} e_{M, t}$ & $\begin{array}{c}0.53 \\
(4.69) \\
{[0.16]}\end{array}$ & $\begin{array}{c}1.13 \\
(5.93) \\
{[0.24]}\end{array}$ & $\begin{array}{c}2.00 \\
(7.12) \\
{[0.28]}\end{array}$ & $\begin{array}{c}2.03 \\
(3.14) \\
{[0.14]}\end{array}$ & $\begin{array}{c}1.45 \\
(1.89) \\
{[0.05]}\end{array}$ & $\begin{array}{c}0.77 \\
(1.07) \\
{[0.01]}\end{array}$ \\
\hline 3 & $\eta_{e, t}$ & $\begin{array}{c}0.19 \\
(3.67) \\
{[0.06]}\end{array}$ & $\begin{array}{c}0.25 \\
(2.90) \\
{[0.04]}\end{array}$ & $\begin{array}{c}0.02 \\
(0.20) \\
{[-0.01]}\end{array}$ & $\begin{array}{r}-0.45 \\
(-2.55) \\
{[0.02]}\end{array}$ & $\begin{array}{r}-0.37 \\
(-1.34) \\
{[0.01]}\end{array}$ & $\begin{array}{l}-0.12 \\
(-0.44) \\
{[-0.00]}\end{array}$ \\
\hline 4 & $\eta_{d, t}$ & $\begin{array}{c}0.09 \\
(0.68) \\
{[-0.00]}\end{array}$ & $\begin{array}{c}0.15 \\
(0.94) \\
{[-0.00]}\end{array}$ & $\begin{array}{c}0.39 \\
(1.49) \\
{[0.00]}\end{array}$ & $\begin{array}{c}0.18 \\
(0.36) \\
{[-0.00]}\end{array}$ & $\begin{array}{c}0.03 \\
(0.07) \\
{[-0.01]}\end{array}$ & $\begin{array}{l}-0.10 \\
(-0.23) \\
{[-0.01]}\end{array}$ \\
\hline 5 & $\eta_{e, t}+\eta_{d, t}$ & $\begin{array}{c}0.21 \\
(3.50) \\
{[0.08]}\end{array}$ & $\begin{array}{c}0.30 \\
(3.02) \\
{[0.05]}\end{array}$ & $\begin{array}{c}0.12 \\
(1.07) \\
{[-0.00]}\end{array}$ & $\begin{array}{r}-0.42 \\
(-3.08) \\
{[0.01]}\end{array}$ & $\begin{array}{r}-0.37 \\
(-1.58) \\
{[0.01]}\end{array}$ & $\begin{array}{l}-0.15 \\
(-0.68) \\
{[-0.00]}\end{array}$ \\
\hline 6 & $E_{t-1} e_{M, t}$ & $\begin{array}{c}0.53 \\
(4.84)\end{array}$ & $\begin{array}{c}1.13 \\
(6.17)\end{array}$ & $\begin{array}{c}2.00 \\
(7.55)\end{array}$ & $\begin{array}{c}2.01 \\
(3.12)\end{array}$ & $\begin{array}{c}1.44 \\
(1.86)\end{array}$ & $\begin{array}{c}0.76 \\
(1.07)\end{array}$ \\
\hline & $\eta_{e, t}$ & $\begin{array}{c}0.22 \\
(3.73)\end{array}$ & $\begin{array}{c}0.30 \\
(2.95)\end{array}$ & $\begin{array}{c}0.09 \\
(0.81)\end{array}$ & $\begin{array}{c}-0.45 \\
(-2.92)\end{array}$ & $\begin{array}{l}-0.38 \\
(-1.42)\end{array}$ & $\begin{array}{l}-0.14 \\
(-0.53)\end{array}$ \\
\hline & $\eta_{d, t}$ & $\begin{array}{c}0.20 \\
(1.53) \\
{[0.24]}\end{array}$ & $\begin{array}{c}0.29 \\
(1.72) \\
{[0.29]}\end{array}$ & $\begin{array}{c}0.40 \\
(1.87) \\
{[0.28]}\end{array}$ & $\begin{array}{r}-0.09 \\
(-0.27) \\
{[0.15]}\end{array}$ & $\begin{array}{r}-0.20 \\
(-0.64) \\
{[0.05]}\end{array}$ & $\begin{array}{r}-0.18 \\
(-0.56) \\
{[0.00]}\end{array}$ \\
\hline & $L R$ & 10.40 & 23.96 & 43.37 & 31.30 & 12.87 & 3.28 \\
\hline
\end{tabular}

NOTE: This table reports the ordinary least-squares (OLS) regression results of real fixed residential investment growth on excess stock market return and its three components. Newey-West (1987) corrected standard errors are used to calculate the $t$ statistics, which are reported in parentheses. The adjusted $R^{2}$ is reported in brackets. $L R$, the statistic of log-likelihood ratio test of equal coefficients in row 6, has a $\chi^{2}$ distribution with two degrees of freedom and its critical value at the 5 percent significance level is 5.99. The data are quarterly and span from 1953:Q1 to 1997:Q4 because of the leads in the dependent variable. The decomposition is based on the VAR estimation reported in Table 2. See Appendix A for a description of the data.

sumption growth up to four quarters. The associated adjusted $\mathrm{R}^{2}$ peaks at a one-quarter horizon, indicating that consumption actually reacts to capital gain/ loss quickly. Again, the total shock, $\eta_{e, t}+\eta_{d, t}$, exhibits very similar predictive patterns to those of $\eta_{e, t}$.

Consumption reacts differently to $\eta_{d, t}$ and $\eta_{e, t}$ for two possible reasons. First, dividend shocks account for a relatively small portion of variations in excess stock market return, as reported in Table 3. Second, Table 4 also shows that $\eta_{e, t}$ has a much larger standard error than $\eta_{d, t}$ has. In other words, there is greater uncertainty associated with shocks to the expected future return than with shocks to dividends. As a result, consumers react with more caution to $\eta_{e, t}$ than to $\eta_{d, t}$. Consistent with the second hypothesis, I find that consumption reacts contemporaneously to dividend shocks, but not shocks to the expected return. Another interesting observation is that, unlike nonresidential investment, row 6 shows that the adjusted $R^{2}$ in the multivariate regressions is not substantially higher than its counterpart in row 1. Also, the null hypothesis that the three components have the same coefficient is not rejected by the log-likelihood ratio test in any cases.

\section{Durable Consumption and Fixed Residential Investment}

Table 6 reports the regression results of durable consumption. Excess stock market return, $e_{M, t}$, is 


\section{Table 8}

\section{Forecasting GDP Growth}

\begin{tabular}{|c|c|c|c|c|c|c|c|}
\hline \multirow[b]{2}{*}{ Row } & \multirow[b]{2}{*}{ Regressor } & \multicolumn{6}{|c|}{ Forecast horizon } \\
\hline & & 1 & 2 & 4 & 8 & 12 & 16 \\
\hline 1 & $e_{M, t}$ & $\begin{array}{c}1.03 \\
(3.21) \\
{[0.07]}\end{array}$ & $\begin{array}{c}0.08 \\
(4.09) \\
{[0.14]}\end{array}$ & $\begin{array}{c}0.12 \\
(4.36) \\
{[0.13]}\end{array}$ & $\begin{array}{c}0.09 \\
(3.41) \\
{[0.03]}\end{array}$ & $\begin{array}{c}0.07 \\
(2.60) \\
{[0.01]}\end{array}$ & $\begin{array}{c}0.05 \\
(1.66) \\
{[0.00]}\end{array}$ \\
\hline 2 & $E_{t-1} e_{M, t}$ & $\begin{array}{c}1.04 \\
(1.76) \\
{[0.02]}\end{array}$ & $\begin{array}{c}0.12 \\
(2.46) \\
{[0.07]}\end{array}$ & $\begin{array}{c}0.27 \\
(3.27) \\
{[0.16]}\end{array}$ & $\begin{array}{c}0.35 \\
(3.48) \\
{[0.14]}\end{array}$ & $\begin{array}{c}0.32 \\
(3.01) \\
{[0.08]}\end{array}$ & $\begin{array}{c}0.27 \\
(2.45) \\
{[0.05]}\end{array}$ \\
\hline 3 & $\eta_{e, t}$ & $\begin{array}{c}0.03 \\
(2.35) \\
{[0.04]}\end{array}$ & $\begin{array}{c}0.05 \\
(2.82) \\
{[0.05]}\end{array}$ & $\begin{array}{c}0.04 \\
(1.97) \\
{[0.01]}\end{array}$ & $\begin{array}{l}-0.02 \\
(-0.72) \\
{[-0.00]}\end{array}$ & $\begin{array}{l}-0.03 \\
(-0.70) \\
{[-0.00]}\end{array}$ & $\begin{array}{l}-0.03 \\
(-0.73) \\
{[-0.00]}\end{array}$ \\
\hline 4 & $\eta_{d, t}$ & $\begin{array}{c}0.00 \\
(0.15) \\
{[-0.01]}\end{array}$ & $\begin{array}{c}0.04 \\
(1.19) \\
{[0.00]}\end{array}$ & $\begin{array}{c}0.11 \\
(2.87) \\
{[0.02]}\end{array}$ & $\begin{array}{c}0.12 \\
(1.87) \\
{[0.01]}\end{array}$ & $\begin{array}{c}0.09 \\
(1.64) \\
{[0.00]}\end{array}$ & $\begin{array}{r}0.07 \\
(0.83) \\
{[-0.00]}\end{array}$ \\
\hline 5 & $\eta_{e, t}+\eta_{d, t}$ & $\begin{array}{c}0.03 \\
(2.67) \\
{[0.04]}\end{array}$ & $\begin{array}{c}0.07 \\
(3.55) \\
{[0.08]}\end{array}$ & $\begin{array}{c}0.07 \\
(2.92) \\
{[0.03]}\end{array}$ & $\begin{array}{c}0.01 \\
(0.27) \\
{[-0.01]}\end{array}$ & $\begin{array}{c}-0.01 \\
(-0.19) \\
{[-0.01]}\end{array}$ & $\begin{array}{l}-0.02 \\
(-0.43) \\
{[-0.01]}\end{array}$ \\
\hline 6 & $E_{t-1} e_{M, t}$ & $\begin{array}{c}0.04 \\
(1.88)\end{array}$ & $\begin{array}{c}0.12 \\
(2.65)\end{array}$ & $\begin{array}{c}0.27 \\
(3.51)\end{array}$ & $\begin{array}{c}0.35 \\
(3.73)\end{array}$ & $\begin{array}{c}0.32 \\
(3.16)\end{array}$ & $\begin{array}{c}0.27 \\
(2.49)\end{array}$ \\
\hline & $\eta_{e, t}$ & $\begin{array}{c}0.03 \\
(2.63)\end{array}$ & $\begin{array}{c}0.07 \\
(3.30)\end{array}$ & $\begin{array}{c}0.06 \\
(2.56)\end{array}$ & $\begin{array}{c}-0.00 \\
(-0.13)\end{array}$ & $\begin{array}{c}-0.02 \\
(-0.39)\end{array}$ & $\begin{array}{l}-0.02 \\
(-0.53)\end{array}$ \\
\hline & $\eta_{d, t}$ & $\begin{array}{c}0.02 \\
(1.06) \\
{[0.06]}\end{array}$ & $\begin{array}{c}0.08 \\
(2.57) \\
{[0.15]}\end{array}$ & $\begin{array}{c}0.14 \\
(3.49) \\
{[0.20]}\end{array}$ & $\begin{array}{c}0.12 \\
(2.13) \\
{[0.15]}\end{array}$ & $\begin{array}{c}0.08 \\
(1.58) \\
{[0.08]}\end{array}$ & $\begin{array}{c}0.05 \\
(0.74) \\
{[0.04]}\end{array}$ \\
\hline & $L R$ & 0.66 & 2.65 & 17.13 & 24.31 & 14.52 & 8.84 \\
\hline
\end{tabular}

NOTE: This table reports the ordinary least-squares (OLS) regression results of real GDP growth on excess stock market return and its three components. Newey-West (1987) corrected standard errors are used to calculate the $t$ statistics, which are reported in parentheses. The adjusted $R^{2}$ is reported in brackets. $L R$, the statistic of log-likelihood ratio test of equal coefficients in row 6 , has a $\chi^{2}$ distribution with two degrees of freedom and its critical value at the 5 percent significance level is 5.99 . The data are quarterly and span from 1953:Q1 to 1997:Q4 because of the leads in the dependent variable. The decomposition is based on the VAR estimation reported in Table 2. See Appendix A for a description of the data.

positively correlated with the future durable consumption growth at all horizons. However, its forecasting power concentrates over relatively short horizons and peaks at two quarters with an adjusted $\mathrm{R}^{2}$ of 19 percent. The predictive pattern is also quite different among its three components. The expected return, $E_{t-1} e_{M, t}$, is positively correlated with future durable consumption growth at all horizons, and its forecasting power peaks at one year with an adjusted $\mathrm{R}^{2}$ of 16 percent. In contrast, shocks to the expected future return, $\eta_{e, t}$, are positively correlated with future durable consumption over short horizons and the correlation turns negative as the horizon increases. Their predictive power peaks at two quarters with an adjusted $R^{2}$ of 7 percent. Again, I find that the forecasting power of dividend shocks, $\eta_{d, t}$, is rather limited: It peaks around one year with an adjusted $R^{2}$ of 1 percent. Also, the forecasting power of total shocks $\eta_{e, t}+\eta_{d, t}$ displays similar patterns to those of $\eta_{e, t}$. Because of their different predictive patterns, row 6 shows that the joint forecasting power of the three components of excess stock market return is larger than its counterpart in row 1 , especially over long horizons. Also, the null hypothesis that the three components have the same coefficient is overwhelmingly rejected in many cases. Table 7 reports the regression results of fixed residential investment, which are qualitatively similar to those of durable consumption, as reported in Table 6 (although it is not discussed in detail here). 
To summarize, I find that durable consumption and fixed residential investment show many similarities to fixed nonresidential investment. This finding is not a surprise because durable consumption and fixed residential investment can be thought of as investment in home productions. However, there is one notable difference. It is well known that durable consumption and fixed residential investment tend to lead fixed nonresidential investment. Gomme, Kydland, and Rupert (2001) have emphasized this feature of the data in business cycle modeling. In my paper, this is reflected by the fact that durable consumption and fixed residential investment tend to respond to excess stock market return and its components much faster than fixed nonresidential investment does.

\section{GDP}

Table 8 reports the regression results of GDP. Excess stock market return, $e_{M, t}$, is positively correlated with future GDP growth over all horizons, and its predictive power peaks at two quarters with an adjusted $R^{2}$ of 14 percent. Its components, however, display quite different predictive patterns. The expected return, $E_{t-1} e_{M, t}$, is also positively correlated with future GDP growth at all horizons, and its predictive power peaks at two years with an adjusted $\mathrm{R}^{2}$ of 16 percent. In contrast, shocks to the expected future return, $\eta_{e, t}$, are positively correlated with future GDP growth at short horizons and the correlation turns negative as forecasting horizons increase. Their predictive power peaks at two quarters with an adjusted $R^{2}$ of 5 percent. Interestingly, dividend shocks are always positively correlated with future GDP growth; however, their predictive power is weak, as I find for the GDP components above. Not surprisingly, row 6 shows that the joint predictive power of the three components is much stronger than its counterpart in row 1, especially over long horizons. Also, the null hypothesis that the three components have the same coefficient is rejected in many cases.

\section{CONCLUSION}

In this paper, I first summarize recent evidence against the random walk hypothesis of stock price. Using post-World War II data, I find that over 20 percent of variations in quarterly excess stock market return are explained by past stock market variance and other informational variables. I then analyze the predictive power of excess stock market return for economic activities by decomposing it into three parts: expected return, shocks to the expected future return, and shocks to the expected future dividend. I find that stock price is not sensitive to dividend news, and, therefore, the dividend component has little predictive power for GDP and its components. In contrast, the expected return and shocks to the expected future return, especially the former, are strong predictors for economic activities. However, their predictive patterns are quite different, especially over long horizons. Together, my results explain why the predictive power of stock market returns is rather limited.

\section{REFERENCES}

Barro, Robert J. “The Stock Market and Investment.” Review of Financial Studies, 1990, 3(1), pp. 115-31.

Campbell, John Y. and Shiller, Robert J. “The Dividend-Price Ratio and Expectations of Future Dividends and Discount Factors." Review of Financial Studies, 1988, 1, pp. 195-227.

and Ammer, John. "What Moves the Stock and Bond Markets? A Variance Decomposition for Long-Term Asset Returns.” Journal of Finance, March 1993, 48(1), pp. 3-37.

; Lo, Andrew W. and MacKinlay, A. Craig. The Econometrics of Financial Markets. Princeton: Princeton University Press, 1997.

; Lettau, Martin; Malkiel, Burton G. and Xu, Yexiao. "Have Individual Stocks Become More Volatile? An Empirical Exploration of Idiosyncratic Risk." Journal of Finance, February 2001, 56(1), pp. 1-43.

Fama, Eugene F. "Stock Return, Real Activity, Inflation, and Money.” American Economic Review, September 1981, 71(4), pp. 545-65.

Fisher, Stanley and Merton, Robert C. "Macroeconomics and Finance: The Role of the Stock Market." CarnegieRochester Conference Series on Public Policy, 1984, 21, pp. 57-108.

Gomme, Paul; Kydland, Finn E. and Rupert, Peter. "Home Production Meets Time to Build." Journal of Political Economy, October 2001, 109(5), pp. 1115-31.

Guo, Hui. "Limited Stock Market Participation and Asset Prices in a Dynamic Economy." Working Paper 2000031A, Federal Reserve Bank of St. Louis, 2000. 
"Stock Market Returns, Volatility, and Future Output.” Working paper, Federal Reserve Bank of St. Louis, 2001.

"Understanding the Risk-Return Tradeoff in the Stock Market.” Working Paper 2002-001A, Federal Reserve Bank of St. Louis, 2002.

Hall, Robert E. "Stochastic Implications of the Life CyclePermanent Income Hypothesis: Theory and Evidence." Journal of Political Economy, 1978, 86(6), pp. 971-87.

Lamont, Owen A. "Investment Plans and Stock Returns." Journal of Finance, December 2000, 55(6), pp. 2719-45.

Lettau, Martin and Ludvigson, Sydney. "Consumption, Aggregate Wealth, and Expected Stock Returns.” Journal of Finance, June 2001a, 56(3), pp. 815-49.

and "Time-Varying Risk-Premia and the Cost of Capital: An Alternative Implication of the q Theory of Investment." Journal of Monetary Economics, 2001b (forthcoming).
Merton, Robert C. "An Intertemporal Capital Asset Pricing Model.” Econometrica, 1973, 41, pp. 867-87.

"On Estimating the Expected Return on the Market: An Exploratory Investigation.” Journal of Financial Economics, December 1980, 8(4), pp. 323-61.

Newey, Whitney K. and West, Kenneth D. "A Simple, Positive Semi-Definite, Heteroskedasticity and Autocorrelation Consistent Covariance Matrix.” Econometrica, May 1987, 55(3), pp. 703-08

Schwert, G. William. "Indexes of U.S. Stock Prices from 1802 to 1987." Journal of Business, July 1990, 63(3), pp. 399-426.

Stock, James H. and Watson, Mark W. "Business Cycle Fluctuations in U.S. Macroeconomic Time Series," in J. Taylor and M. Woodford, eds., Handbook of Macroeconomics, Vol. 1A. Amsterdam: Elsevier, 1999, pp. 3-64.

Appendix A

\section{DATA DESCRIPTION}

\section{Stock Market Return and Its Forecasting Variables}

\section{Consumption-Wealth Ratio: $\operatorname{cay}_{t}$}

Source: < www.newyorkfed.org/rmaghomel economist/lettau/data.html $>$.

\section{S\&P 500 Dividend Yield: $d p_{t}$}

Last four-quarter dividends divided by stock price using S\&P 500 stocks. Source: Haver Analytics (2001).

\section{Stochastically Detrended Risk-Free Rate: $\boldsymbol{r r e l}_{\boldsymbol{t}}$} Risk-free rate less its last four-quarter average or

$$
\operatorname{rrel}_{t}=r_{f, t}-\frac{1}{4} \sum_{k=1}^{4} r_{f, t-k},
$$

where $r_{f, t}$ is the nominal risk-free rate. I construct the quarterly nominal risk-free rate by summing up the monthly rate within each quarter. Source: CRSP, Center for Research in Security Prices. Graduate School of Business, The University of Chicago, 2002. Used with permission. All rights reserved. < www.crsp.uchicago.edu > .

\section{Excess Stock Market Return: $\boldsymbol{e}_{M, t}$}

Value-weighted stock market return less the nominal risk-free rate. Source: CRSP.

\section{Stock Market Variance: $\sigma_{M, t}$}

Sum of the squared deviation of daily excess stock market return for its quarterly average, or

$$
\sigma_{M, t}=\sum_{j=1}^{\tau}\left(e_{M, t \tau}-\bar{e}_{M, \tau}\right)^{2},
$$

where $e_{M, t \tau}$ is the daily excess stock market return and $\bar{e}_{M, t}$ is its average in quarter $t$. The daily riskfree rate is assumed to be equal to the monthly rate divided by the number of trading days. Source: I use the daily market return constructed by Schwert (1990) before July 2, 1962, and use the daily valueweighted market return (VWRET) from CRSP thereafter; the nominal monthly risk-free rate is also from CRSP. Following Campbell et al. (2001), I downweight stock market variance during the 1987 stock market crash.

\section{National Accounts Data}

Source: Bureau of Economic Analysis. 


\section{Appendix B}

\section{DERIVATION OF THE SHOCK TO THE EXPECTED FUTURE RETURN}

From equation (8), it is straightforward to show that

$$
E_{t} X_{t+j}=A+B A+\cdots+B^{j-1} A+B^{j} X_{t},
$$

and

(B2) $\quad E_{t-1} X_{t+j}=A+B A+\cdots+B^{j} A+B^{j+1} X_{t-1}$.

Then

(B3)

$$
\begin{aligned}
& -\left(E_{t}-E_{t-1}\right) \sum_{j=1}^{\infty} \rho^{j} X_{t+j} \\
& =-\sum_{j=1}^{\infty} \rho^{j}\left[A+B A+\cdots+B^{j-1} A+B^{j} X_{t}-A-B A-\cdots-B^{j} A-B^{j+1} X_{t-1}\right] \\
& =-\sum_{j=1}^{\infty} \rho^{j}\left[B^{j}\left(X_{t}-X_{t-1}\right)-B^{j} A\right] \\
& =-\sum_{j=1}^{\infty} \rho^{j}\left[B^{j} A+B^{j} \varepsilon_{t}-B^{j} A\right] \\
& =-\rho B(I-\rho B)^{-1} \varepsilon_{t} .
\end{aligned}
$$

Because $e_{M, t}$ is the first row of $X_{t}$,

(B4)

$$
\begin{aligned}
& -\left(E_{t}-E_{t-1}\right) \sum_{j=1}^{\infty} \rho^{j} e_{M, t+j} \\
& =-e 1^{\prime}\left(E_{t}-E_{t-1}\right) \sum_{j=1}^{\infty} \rho^{j} X_{t+j} \\
& =-e 1^{\prime} \rho B(I-\rho B)^{-1} \varepsilon_{t} .
\end{aligned}
$$


